\title{
A New Public Education for England
}

\author{
JOHN WHITE
}

\begin{abstract}
This is an argument for a new public education for England, but not for a new public school. The focus should be on aims, not structures. We should ensure that all schools (community schools, private schools, academies and religious schools) are working to realise the same nationally determined aims. The national set of aims should be determined not by ministers but by a Curriculum Commission. Its starting point should be the protection and nurturing of a liberal democratic community. This generates a number of major aims from which the Commission will also lay down more specific ones. Schools should be free to employ their own curricular vehicles (e.g.

subjects, projects, whole-school processes) and other policies in pursuing these aims.
\end{abstract}

\section{A New Public School}

I am in favour of a new public education for England, but whether it should be in a new public school is another matter. Supporters of a new public school are likely to be in the tradition that has come down to us via Tawney, Halsey and Tim Brighouse in favour of a common (comprehensive) school for all students and run by local authorities. The strictest among them may want to abolish all academies and private schools; others may favour less radical policies, like Labour's plan to disallow new free schools and to oppose attempts to force schools to become academies (Labour Party, 2017, p. 37). Some, too, may have faith schools in their sights and seek ways to abolish or curtail those in the academy or private sectors, if not also those within the maintained sector.

I can understand why people think in these ways. Pressure for a common school has been within the broad egalitarian tradition in politics. A more specific egalitarian reason, recently applying especially to academies, has been antipathy towards the privatising project of rolling back the state and the increasing gap between rich and poor that this has helped to create. A third reason, based on liberty rather than (directly) on equality, has been a concern that faith school students not be indoctrinated. 
As someone attached to the democratic values of equality and personal autonomy, I sympathise with these considerations. But not wholly, especially in what I have called the 'strictest' sense of the 'new public school', to do with making all schools maintained comprehensives. As I understand democratic equality, it is about everyone showing equal respect to other members of the political community and trying to ensure that everyone has a sufficiency of the goods needed to lead a flourishing life, not about ensuring that everybody is provided with the same goods. Sending every student to a comprehensive does not rule out a hierarchy of such schools, whereby more advantaged families through residence and school-choice mechanisms can place their children in highly favoured ones while others have to make do with the rest. This would make a society based on democratic equality harder to achieve.

As for the academies project, the severe reservations I expressed about it above (and there are more specific objections, to do, for instance, with constraints on the autonomy of schools run by large multi-academy trusts and the use of public money to pay the excessive salaries of some of its leaders) are certainly grounds for subjecting it to greater political control, but the mere fact that it involves putting what was previously in the public domain into private hands is not necessarily a defect. Hospital and university eating places in the form of cafés run by major coffee franchises can outshine what used to be provided in-house. Some academies, including free schools, may and perhaps do provide higher-quality education than some community schools.

I realise that what counts as an education of higher quality is open for discussion. But, in a study based on pupil-level outcomes at Key Stages 2 and 4, there is at least evidence that 'after controlling for other relevant characteristics, pupils in small and mid-sized multi-academy trusts tend to perform better, on average, than their peers in comparable maintained schools in both phases' (Greany \& Higham, 2018, pp. 89-90). A specific example of an academy providing what seems by all accounts to be a high-quality education (and one not in thrall to test and examination success) is School 21, the 4-18 free school in Stratford, East London (https://www.school21.org.uk).

But my main objection to the idea of a new public school (in any variant) is that by focusing on institutions it puts the spotlight in the wrong place. Institutions are vehicles to help realise what are seen as worthwhile ends. It is on ends that we should first focus, not mechanisms. That would be like identifying democratic decision-making with majority voting or asking which school subjects should be included in the curriculum. Majority voting and school subjects are only vehicles - possible ways of realising democratic values on the one hand and educational aims on the other.

\section{A New Public Education and Current Educational Aims}

That is why I favour a new public education rather than a new public school. I shall understand 'a new public education' to imply, among other things, an educational system guided by common worthwhile aims. And by 'guided' I don't 
mean that aims statements are merely included in official documents. I mean that the worthwhile aims permeate every aspect of a school's life. It is from them that more specific curricular objectives are to be generated, as well as teaching methods, assessment systems, ethos and forms of internal school government. I will later flesh out this notion of 'worthwhile aims'. Meanwhile I want to show how far our present educational system is from a 'new public education' as defined.

The current official position on schools' aims is this: the curriculum of all state-funded schools, including academies, must be such that it (a) 'promotes the spiritual, moral, cultural, mental and physical development of pupils at the school and of society' and (b) 'prepares pupils at the school for the opportunities, responsibilities and experiences of later life' (Department for Education, 2014, 2.1). Call this combination of (a) and (b) 'Aim 1'.

Maintained schools, unlike academies, are subject to the national curriculum and must also follow its aims: 'The national curriculum provides pupils with an introduction to the essential knowledge they need to be educated citizens. It introduces pupils to the best that has been thought and said, and helps engender an appreciation of human creativity and achievement' (Department for Education, 2014, 3.1) (Aim 2).

Private schools need not follow either aim.

I know of no evidence that schools bound by Aims 1 or 2 are in general guided by them, in the sense that they permeate every aspect of the school's life. The aims are, in any case, too often inadequately expressed. Take the meaningless injunction of Aim 1 that schools should promote the physical development of society. Close behind is the tautology in Aim 2 embedded in 'the essential knowledge they need to be educated citizens'. Among others, the terms 'spiritual' and 'cultural' development are capable of many different meanings, some of them controversial. Aim 1(b) is platitudinous.

\section{Academies' Aims}

There is a further problem about academies' aims in particular. As academies need not follow the national curriculum, they need not follow its aims and, while they must take Aim 1 (above) into account, they are free to arrange their own specific curricular objectives and more general aims. I leave to one side the fact that academies' stated aims often suffer from many of the inadequacies mentioned above. A more basic issue concerns whether academies have the moral as distinct from the legal right to determine their own aims, including the more specific curricular ones.

Before the 1988 national curriculum, maintained schools were legally free to do exactly this. But then came the question: what right do teachers have that others in the wider community lack to decide what the education in their school should be for? This question takes one into deep ethical waters: about the nature of a fulfilling life, about the kind of community we should live in, and about much else besides. Teachers may well be experts on how children learn 
and how to teach them, but they have no unique insight into how we should live, personally and communally. No section of the political community has this. It is one of the hallmarks of a democratic polity that no one has such a privileged insight before which everyone else should bow down: all of us as equal citizens should be able to participate in communal decision-making about people's welfare and how we should live together.

In 1988 it was right, therefore, to remove aims from professional control and place them under democratic control. I will come back later to the question of whether the kind of democratic control favoured in 1988 is defensible. My present concern is with academies and their freedom to decide their own aims.

The argument against leaving aims in schools' hands before 1988 applies to academies too. It is not only educational professionals in academies and academy chains who help to determine aims, but also people with a background in business, finance and other sectors. In a democracy, no section of the community - educational professionals, business people or anyone else - has privileged credentials to decide what education should be for.

\section{Private School Aims}

Does the problem of leaving academies free to set their own aims apply also to private schools? It would seem to be so, since those responsible for their aims, whether teachers or governors, likewise have no special expertise on what counts as the good of the individual or of the wider community.

True, this seems to assume that private schools belong to the same nationwide system of education as publicly funded ones, whether maintained or academies. It is because publicly funded schools are part of a national education system, which in turn is part of a democratic political community, that their aims should be determined by the latter. If it can be shown that private schools are not part of this national system, the problem of their setting their own aims may well disappear. So the question is: are private schools part of a national system of education, or not?

Features of their history, not least their recent history, may well suggest that they should be. Scholarships, direct grants and assisted places for children who would otherwise have gone to state schools are examples. Since 1992 private schools have been included with state schools in local league tables. In recent decades, too, to protect their charitable status they have been officially encouraged to strengthen links with state schools. The spread of privatisation via the academy programme especially since 2010 has blurred the distinction between public and private education (White, 2015). It is easy these days to see private schools at one end of a private-public spectrum, with academies lying somewhere between them at one end and maintained schools at the other.

If private schools are part of the same national system as academies and maintained schools, we have a reason why they, along with these others, should be bound by democratically determined aims and curricula. They, too, would be vehicles of the 'new public education' argued for in this article. 
Could one reasonably deny that private schools are part of a national system and so subject to its aims? One argument is that it is parents who pay for these schools and who should be free to do what they want with their own money: if they want the schools to set their own aims, they should be allowed to do so. But there are limits to what these parents and schools should be allowed to do. They should not, for instance, indoctrinate children into a narrow religious or political faith as this would jeopardise their turning into autonomous adults. This objection is based on the democratic value of autonomous well-being.

It would also offend egalitarian democratic values if a central aim of the schools was to prepare students for elite leadership positions. I suspect that many parents do go private for this reason. Private schools often explicitly include leadership among their stated aims, but even when they do not, they tend to have an ethos of social exclusiveness coupled with a focus on exam results and personal qualities facilitating entry to the best universities. Parents, like schools, are aware of statistics showing that most people in leading positions in professions like law, politics, medicine, journalism and business are among the $7 \%$ of students who are privately educated (White, 2015).

\section{A National Curriculum Commission}

If private schools, academies and maintained schools should all be seen as part of a national system and bound by its aims, who should determine these aims and what should these be? As argued above, aims and curricula should be under some form of democratic control. Experience since 1988 has shown that they should not be decided by education ministers as they may be swayed by their own prejudices. There is a good argument for aims to be put in the hands of a National Curriculum Commission at arm's length from government (White, 2010). This would represent sectors of society with a major stake in the education and well-being of young people, such as teacher unions, universities, local authorities, parents and employers. Its recommendations would be fully discussed in public, via print and the internet, before final decisions were taken. Its task would be to devise aims reflecting the democratic values that provide the rationale for a national educational system. A separate national monitoring authority - which could be a remodelled version of Ofsted - should see that all schools abide by the national aims, not in some lip-serving sense, but by bringing all their activities in line with them.

As to what the aims should be, the starting point must be the values of democracy. The democrat wants everyone, not only a privileged section of society, to have the wherewithal to lead a flourishing life of their own choosing, to help others also to lead such a life, and to take seriously their membership of the communities of different sorts - national, local, vocational, etc. - that can further these two aims. Brighouse et al (2016) spell out six 'educational goods' that are broadly in line with this: capacities for economic productivity; personal autonomy; democratic competence; healthy personal relationships; treating 
others as equals; and personal fulfilment. Reiss and White (2013) have produced a fuller account much in tune with this.

There is likely to be sufficient consensus in this area for a Curriculum Commission to lay down what general aims schools should follow. With regard to personal autonomy, for instance, schools should acquaint students with options in the areas of personal fulfilment and economic productivity so that they can make choices at school and later about what kind of life they want to lead, what kinds of personal relationships to enter into and what kind of job to do. Some of this opening up of options will depend on an understanding and an experience of science, maths and other fields included in the present national curriculum, but it should be up to schools and not the Commission to decide whether these fields are taught via discrete subjects or in other (e.g. interdisciplinary) ways, and in what circumstances. A balance will also have to be struck between opening up options and allowing students plenty of time to engage in those options which they find they most enjoy (Sardoc \& White, 2017).

These various prescriptions apply not only to personal autonomy aims but also to those concerning other people's welfare. (The two aspects are indeed to a large degree inseparable, as choosing to become a doctor and making decisions about matters of personal relationships illustrate.) Schools will reinforce democratic values and capacities in every aspect of their life, values such as treating others as equals, toleration, willingness to compromise, working for the welfare of all within the school community or in wider communities. This will go hand in hand with a deepening understanding of democracy as a form of living together, both at a more abstract level and against the background of historical and present realities.

It will be up to the national monitoring authority to see to it that schools pursue such aims in every facet of their work. It will not do, for instance, for schools to be as orientated towards test and exam success as so many of them are now. Amanda Spielman, Ofsted's chief inspector, is right in her misgivings about the role this plays in rating schools, even if her suggested reforms bound as they are by current legislation - do not go far enough (White, 2019). We need creative thinking about how monitoring can best take place - for example, about what role traditional inspection and school self-evaluation should play, about possibilities opened up by the digital revolution, and about sanctions against schools perverting the true picture of what is happening inside them.

\section{Private Schools, Faith Schools, Grammar Schools}

I wrote above that "I shall understand "a new public education" to imply, among other things, an educational system guided by common worthwhile aims'. There is more to be said about these 'other things'. Take private schools. With democratic equality in mind, measures will be necessary to reduce their role in dominating access to the best universities and elite professions. Quotas for 
university admissions from them could be reduced, for instance, to something close to the $7 \%$ of students now educated privately. Private schools will also have to provide evidence, by offering significantly more scholarships and by carrying out (non-token) work in the community, that they are serving the common good and not helping to perpetuate an elite.

All faith schools, whether maintained, academies or private, will have to follow the new national aims. Since this means enabling students to lead autonomous lives, these schools will be debarred from using their ethos or teaching arrangements to reinforce or implant belief in a faith. In the interests of social integration, they will be obliged to limit students from their own faith to not more than $50 \%$ (see Clayton et al, 2018).

Grammar schools and other elite maintained schools and academies, as well as some faith schools, are magnets for more affluent families. There are well-rehearsed and solid reasons for abolishing grammars - and to that extent they constitute an exception to the case I am making in this article - but while they continue to exist, they too should be subject to the new common aims. So as to minimise over-representation of the affluent among elite professions, for grammars and other higher-end maintained schools, as with private schools, we should be looking at quotas for university entrance.

\section{Conclusion}

These are some measures necessary to reverse the past and present tendency of the education system to perpetuate a hierarchical society in which the more fortunate pass on their advantages to later generations while allowing a few from lower strata to join them, under the banner of 'equality of opportunity'. There will also have to be other reforms in the same direction, some within the education system (perhaps including lotteries for admission to maintained schools), and some outside it (e.g. higher taxation for the rich and changed inheritance legislation).

The new public education, as I have described it, allows schools of varied types to exist, but all will have to be regulated by the same set of national aims, and some - private, faith and elite state schools - will face additional restrictions. How attractive these three sorts of school will still remain to richer or more devout families is a further question.

\section{References}

Brighouse, H., Ladd, H., Loeb, S. \& Swift, A. (2016) Educational Goods and Values: a framework for decision makers, Theory and Research in Education, 14(1). https://doi.org/10.1177/1477878515620887

Clayton, M., Mason, A., Swift, A. \& Wareham, R. (2018) How to Regulate Faith Schools, IMPACT no. 25, Philosophy of Education Society of Great Britain. https://doi.org/10.1111/2048-416x.2018.12005.x 
Department for Education (2014) National Curriculum in England: framework for key stages 1-4. https://doi.org/10.4324/9781315562452-2

Greany, T. \& Higham, R. (2018) Hierarchy, Markets and Networks. London: UCL Institute of Education Press.

Labour Party (2017) Manifesto: towards a National Education Service. https://labour.org.uk/manifesto/accessible-manifesto/

Reiss, M. \& White, J. (2013) An Aims-based Curriculum: the significance of human flourishing for schools. London: Institute of Education Press.

Sardoc, M. \& White, J. (2017) Education and the Adequacy of Options: an interview with John White, Theory and Research in Education, 16(1). https://doi.org/10.1177/1477878517746844

White, J. (2010) The Curriculum, in New Visions for Education Group (Ed.) Much Improved: should do even better?

http://www.newvisionsforeducation.org.uk/2010/03/31/much-improvedshould-do-even-better/

White, J. (2015) What's Wrong with Private Education? London: Institute of Education Press. https://www.ucl-ioe-press.com/ioe-content/uploads/2015/09/Whatswrong- with-private-education.pdf

White, J. (2019) Ofsted's New-look Inspection in Perspective (fuller version of a talk given to a New Visions for Education Group seminar on 17 January 2019). https://www.researchgate.net/publication/330486100_Ofsted's_newlook_inspection_in_perspective

JOHN WHITE is Emeritus Professor of Philosophy of Education at UCL Institute of Education, where he has worked since 1965 after teaching in secondary schools and colleges. His interests are in educational aims and curricula, social justice in education, and the mind of the learner. Correspondence: john.white@ucl.ac.uk 